Reading for law and the state 020309

\title{
Reading for Law and the State: Theaters of Problematization and Authority.
}

History is a reconstruction of the past that seeks a particular kind of fidelity within which the facts acquire their authority. Of all its devices, the narrative is the most compelling for it creates a sequence of factual events and connects them with a dramatic momentum that carries the history from starting point to conclusion... The facts do not exist prior to the interpretation that establishes their significance. Rather, historical research involves a continuous dialogue between the two. ${ }^{1}$

Question: Is there a particular place that brings alive for you the history of the English Civil War?

Diane Purkiss: I'd really like to see Naseby commemorated as Bosworth is; it's incomparably more significant. Bosworth was just a change of dynasty. Naseby changed the world men and women lived in. ${ }^{2}$

\section{Introduction}

My paper concerns the identification and performance of nation, namely that of England at certain points in its formation - England not because it is exceptional, save perhaps in having sped up the arrival of popular sovereignty as a political and legal concept, but principally because its history is one best known to me. ${ }^{3}$ Nation, sometimes understood as community, is an apt study for semiotics because, as many writers have noted, it is the product of narrative, a site of meaning. It is not accidental, moreover, that two ingredients of nation-formation, the play of drama and the drama of war employ the idea of theater. In World War II, the Pacific, the struggles in Burma, Europe and Russia, were all theaters of war in contemporary newsreels and subsequent histories. Characters in theatrical dramas change position and perception; again, in World War II, Stalin, the Bolshevik menace, became, in the Anglophone world, the benign "Uncle Joe" before he became once more a monstrous tyrant.In popular literature and film, especially crime and science fiction, apparently "good" figures turn out to be evil, while those suspected of evil are revealed as upholders of justice. In Don Siegel's 1956 film, Invasion of the Body Snatchers, vicious aliens from outer space, like communists during the US McCarthy era, resemble "normal" Americans, but are actually intent on destroying the environment of law-abiding citizens. Vincente Amorin's 2009 film Good is actually a semiotics of

\footnotetext{
${ }^{1}$ Stuart Macintyre and Anna Clark, The History Wars, Melbourne, Melbourne University Press (2003), 29.

${ }^{2}$ Diane Purkiss, The English Civil War: A People's History, London, Harper (2007), Q and A section, 4. The battle of Bosworth Field, near Leicester, established the Tudor dynasty in 1485, an event, I shall suggest, with perhaps wider ramifications than Purkiss grants it. Nevertheless, Naseby, as we shall see, gradually enabled people to understand their world (in the west) in a new way.

${ }^{3}$ The frequent colloquial conflation of England and Great Britain is a cause of confusion. The United Kingdom is a political contrivance. An Allied Army confronted the Germans in the Great War, but it was as Scottish, French and German men that they played football at Christmas 1914: see Christian Carion's 1995 film, Joyeux Noel.
} 
morality brought uncomfortably close to all of us. We all want to succeed at what we do and most of us want to please people and make people happy. But what if in attempting that we fall into the clutches of those who intend evil outcomes? Does the meaning of our entire life and intentions not entirely change, in retrospect?

Old realities and meanings, in other words, are challenged in both kinds of theater, and new ones are substituted, sometimes temporarily, sometimes permanently. In civil wars, where neighbors and kin, notoriously, often become bitter enemies, this is most noticeable.

I want to take a brief look at the role of both kinds of performance, both kinds of the creation of meaning, both kinds of theater, in the development of Englishness, of how English subjects in the seventeenth century came to know themselves and talk about themselves as certain types of subjects - subjects of law, subjects of rights and government - in the process of that knowing. We cannot expect this talking to take the form of a chorus, even if, as Lacan tells us, the subject is spoken. To be comprehended as a subject in both senses of the term, comprehension, s/he may be creative, but within limits and boundaries that change diachronically, especially in times of stress, but exhibit synchronic similarities. Later, I will refer to an amusing but challenging play on discordance by Tom Stoppard, where the protagonists' belief of the reality they inhabit is sporadically and eventually fatally interrupted by another reality.

For the moment I shall look at some examples of theater, almost exclusively from Shakespeare. He is important to a semiotics of law for a number of reasons which will emerge in relation to the specifics of his dramas. But it is important to suggest at the outset that, as some historians have found, "law" cannot be understood abstractly, "in general”, as Bentham, Kelsen and others would have us believe. This is why I have avoided the expression "legal semiotics", which, like "legal history" suggests an alwaysalready practice to be studied from different, useful, but subaltern positions. At different times and in different places "law" takes on different meanings, and while semiotics, jurisprudences and psychoanalytic theories may offer us alternative pathways into the understanding of normative discourses at a general level, we must always ask, of what is it that we seek to understand: how are we to construct it for our purposes, bearing in mind the kind of fidelity for which Macintyre asks in the quotation at the beginning? The semiotics of what law, whose law, we are enjoined to ask. Shakespeare does ask some pertinent questions we can now look at as semiotics of law questions; what he also does and he was not unique - is to create the material of Englishness, if not for everyone in the geographical boundaries, for deployment as self-knowing identity for some. The semiotics of law in a specific place, looking at a crucial phase of nation-construction, can find the conditions of existence of such an inquiry, perhaps in Kant's sense of critique, in Shakespeare's England.

I also look at the later military dramas of the English civil war, the battles of Marston Moor and Naseby, crucial battles in the mid-1640s which, if they did not make popular government a reality, at least made the discussion of it more than fantasy, especially during the Army Debates at Putney slightly later in the 1640s. I am not, naturally, writing 
literary criticism, history or military or patriotic history, as the quotations at the beginning should make clear. I am concerned with narrative and performance - the semiotics in which subjects reflexively contemplate the rules and conventions by which they consider themselves properly bound - and it is worth stressing the notion of propriety because it contains the issues of how one addresses another peaceably in terms of what they are entitled to expect, something those cultural aristocrats, as Levi-Strauss somewhere terms them, Australian Aborigines were finessing some 35000 years before the rise of the empire of "ancient" Egypt, and Locke struggled with in the 1670s. I am concerned with a particular set of places and times. My period, then, is early modern England, but it is worth quoting Klaas Tindemans, writing of a slightly earlier time, but with an insight highly relevant to my, later, period.

It can hardly be coincidence that, since the Renaissance, there has been a renewed interest in the relation between theater and the political-juridical order. With the disappearance of the medieval world-view, based on a fixed position of both rulers and ruled, on a status being both diachronically and synchronically fixed.. fundamental political categories such as sovereignty and (political) subjectivity have again become problematic. ${ }^{4}$

\section{2) Knowing and imagining in relating the nation}

In Benedict Anderson's well-known formulation, nations are "imagined communities", so "how do we know something beyond the reach of our (direct) experience?" 5 As Neumann remarks, contrary to most of what we know about "knowing", "one way of knowing, he remarks, is regularly considered superior: that of seeing for oneself rather than relying on someone else's description or depiction”. ${ }^{6}$ But history, vital to the imagination of nation as community, is not knowledge of this kind, nor is the subjectmatter of most disciplines and trans-disciplines. In Oliver Sacks' acclaimed study of brain-damaged patients, he noticed that in situations in which a person, as a result of brain trauma, had forgotten who or where s/he was, s/he produced an endless stream of contradictory narratives of themselves. ${ }^{7}$

The imagining of nation operates similarly. White inhabitants of the American colonies were asked by the 1776 Declaration of Independence to believe that their "unalienable", prior-to-the law rights by virtue of the colonists' heritage as "free-born Englishmen to "Life, Liberty and the pursuit of Happiness" justified their secession from the British Empire, in particular from the "usurpations and injuries" inflicted on them by George III and his ministers. This unalienable right in the original Declaration of 1776 signifies an intrinsic quality, or meaning, of law, namely that it ceases to bind where it impinges on freedom, a signifier no doubt of considerable political virtue, but as intangible as its opposite, that law, in this case, Westminster sovereign law, must be obeyed. The

\footnotetext{
${ }^{4}$ Klaas Tindemans, The King's Travesty: The Theatrical Gaze and the Representation of the Political and Legal Order, (1997) X International Journal for the Semiotics of Law 115-139, 133.

${ }^{5}$ Klaus Neumann, but is it history? (2008), 14 Cultural Studies Review 19.

${ }^{6}$ Neumann, op cit.

${ }^{7}$ Oliver Sacks, The Man Who Mistook His Wife for a Hat, New York, Summit Books (1985).
} 
Jefferson Memorial in Washington DC invokes, in a re-writing of the Declaration, "inalienable" rights, something more transcendent, but equally empty except as a signal that here is a space where ethical decisions replace rule-following as a source of obligation. ${ }^{8}$ And here a more singular God than that envisaged by the founders of the republic, refugees from a pre-latitudinarian High Church of England, signifier of omnipotence, begins to make an appearance The official motto of the US, "E Pluribus Unum", a sentiment Barack Obama was to endorse in a 2008 speech in Philadelphia, was replaced as the official motto by "In God We Trust" by an Act of Congress in 1956.By 2002, US Attorney-General Ashcroft invited US citizens to see themselves as free, not "by the grant of any government or document, but (the) endowment of God". ${ }^{9}$ How, Roy asks, can one respond to a regime that believes its policies to re-mold the world in its own image are mandated by a deity equally the regime’s image?

National-community narratives, then, endlessly repeat and equally bewilderingly, change, their meaning of themselves for those who identify with them. That they can do so, like Sacks' brain-damaged patients, can be understood if we follow Lacan's observation that a signifier points, not to an ultimate, or authentic signified - in this case the "real" nation, but to another signifier. In Rupert Brooke's poem, written shortly before his death in the Great War, he wrote of his absent signified, the rule of law constituting his homeland, signaled by its migratory landscapes:

If I should die, think only this of me;

That there is some corner of a foreign field

That is forever England. There shall be

In that rich dust, a richer dust concealed

A dust whom England bore, shaped, made aware,

Gave once her flowers to love, her ways to roam. ${ }^{10}$

Kipling gave us other examples of national signifying. "The Mother.. all Celt, with that flutter of the hands", he wrote in his autobiography, once supplied him with some succinct lines he was trying unsuccessfully to express. What you are trying to say, he tells us she said, is, "What do they know of England, who only England know?" ${ }^{11}$ It is, of course a perfectly sensible sentiment: one must be outside in order to point, but at what is one pointing? The answer can only be, at a representation, a representation of customs, laws and traditions signifying an England known only to those who know something else. Kipling's own characters, the Tommy Atkins's, Irish, English, Welsh and Scots soldiers, also discover and perform their meaning as British rather than English, in Britain's very absence, typically when they are in India or on an outward bound troopship. No IrishAmerican agitator can stir up disaffection among Kipling's Irish soldiers of the Queen in India.

\footnotetext{
${ }^{8}$ Frank Fetter, The Revision of the Declaration of Independence in 1941, (1974) 31 The William and Mary Quarterly $3^{\text {rd }}$ Ser 133-139.

${ }_{9}^{9}$ Quoted in Arundhati Roy, An Ordinary Person's Guide to Empire, New Delhi, Penguin (2006), 54.

${ }^{10}$ Rupert Brooke, The Soldier. His body would lie, he promised his reader, “under an English heaven”.

${ }^{11}$ Rudyard Kipling, Something of Myself, Harmondsworth, Penguin (1977), 86.
} 
For Victorian British administrators, like James Fitzjames Stephen, as well as for writers like Kipling, the soldier from the UK was one of the signs, not only of the potency of British rule, but of European civilization and the English rule of law in a place where these virtues would otherwise be lacking. ${ }^{12}$ TB Macaulay, in typical Whig fashion, saw law as founded on trust, perceived fairness and predictability - these were the signifiers of England and its servants, military and civilian, that inspired loyalty among the "native" regiments. ${ }^{13}$ In the larger world, the world of empire, in Kipling's words, "while it's Tommy this an' Tommy fall be'ind/ But it's please to walk in front, sir, when there's trouble in the wind." 14 At "home", though, Tommy no longer signifies the meaning of the nation constituted by the rule of law, particularly to those who "only England know". When he goes into a pub to buy himself a pint of beer, “the publican, ‘e ups an’ sez, “We serve no redcoats 'ere”.

My article, then, albeit focused on an England formed through drama at important moments in the histories written of it, occupies the now familiar terrain connecting psycho-analysis with semiotics and the semiotics of law, and relies on an equally familiar cartography of that terrain. It looks for meaning, the processes which Lacan refers to as the sinthome, the stitching that holds one or more surfaces together and prevents them from slipping endlessly and arbitrarily. Freud's travels from his early to his later consulting room years, from clinical practice and observation to his broad hypothetical history, and social-theoretical speculations about the deeper causes of subjective characteristics, demonstrate the imbrication of the science (in the original sense of systematic investigation, not canonical truth) of psycho-analysis, and that of meaning, semiotics. ${ }^{15}$ In the ground-breaking, but ultimately perhaps overly reassuring linguistics, the language of language, de Saussure gave us the formula of signifier+signified=sign. ${ }^{16}$ Whilst de Saussure insisted on the arbitrariness of a "slice of sound to a given idea", there was, according to Beneviste, nevertheless, in de Saussure’s texts, "an unconscious and surreptitious recourse to a third term which was not included in the initial definition. This third term is the thing itself" 17 - that is to say, the real. Whilst this interpretation of de Saussure's semiotics may receive some support from Noth's quotation from Alan Gardiner, "Does Beneviste deny that reality is at the base of every concept?"18 de Saussure himself seems less than dogmatic in a way that points through Lacanian structuralist psycho-analysis to the semiotics of law. Thus, de Saussure remarks that

\footnotetext{
${ }^{12}$ James Colaiaco, James Fitzjames Stephen and the Crisis of Victorian Thought, London, Macmillan (1983)

${ }^{13}$ TB Macaulay, Essay on Clive, London, Dent (1920), 87. Ironically, of course, he was writing less than a decade before the Insurrection of 1857.

${ }^{14}$ Rudyard Kipling, Tommy. The nuances of class and ethnicity in the constructions of Kipling's work are startling.

${ }^{15}$ See Veronique Voruz, The Logic of Exception: A Structural Reading of the Foundational Texts of Psychoanalysis, (2006) Law, Culture and the Humanities 162-178; Sovereignty, Power and Resistance (2002) 15 International Journal for the Semiotics of Law 231-252.

${ }^{16} \mathrm{~F}$ de Saussure, Genera Course in Linguistics, London, Fontana (1977).

${ }^{17}$ De Saussure and Beneviste, quoted in Winfried Noth, Handbook of Semiotics, Indianapolis, University of Indiana Press (1995). 244.

${ }^{18}$ Noth, op cit.
} 
It is not the metal in a piece of money that fixes its value.. its value will vary according to the amount stamped on it and according to its use inside or outside a political boundary. ${ }^{19}$

Daniel Defoe had made the point somewhat earlier ${ }^{20}$ : it is mutually accepted networks of rules that govern the significance attached to particular phenomena, whether it is the value inscribed on an otherwise worthless scrap of paper, or coin, Lacan's broad Law of the Father, or the order which, as Foucault was fond of saying, separates the good boys from the bad boys, whether it is the manners that underlay civilized subjectivity and ultimately constitutional legality and peace for Locke and Shaftesbury ${ }^{21}$ or the conventions which, for Hume, explained the possibility of law, government and the peaceful interaction of people. ${ }^{22}$ In all these cases, what semiotics traces is the law behind the law, or the conditions of law's existence.

But we need to add a query hinted at earlier. What is the provenance of the subject? As Lacan puts it many times, law, like truth, is convention, but this is insufficient, he tells us - for whom is the truth a convention and how does it become one. It does not matter, he writes, where the table, like the periodic table used by chemists, perhaps, "hangs out", so long as it provides a set of demanding intersubjective protocols, laws which give a community the capacity to disagree, but by virtue of which at least it knows what its members are talking about - to be, indeed, a community. But, for Lacan, as, one suspects, for Hume, this is not the hotchpotch of liberal conventionalism :

To the extent that we can identify it in terms of the working of the subject, this Other (like the table) is to be defined as the site of speech. This is not where speech is uttered, but where it takes on the value of speech, in other words where it inaugurates the dimension of truth. ${ }^{23}$

Where the Other is, as a quilting point preventing the endless play of surfaces, there the subject can be found.

\section{3) Theatricality and authenticity: the past as the lived (remembered) truth.}

\footnotetext{
${ }^{19}$ Ferdinand de Saussure, General Course in Linguistics, London, Fontana (1977), 118. he might have added "legal” to political, since, in relation to monetary currency, we speak of "legal tender".

${ }^{20}$ Daniel Defoe, Captain Singleton: Life, Adventures and Piracies of Captain Singleton and Life of Colonel Jack, (1720), London, Henry Bohn MDCCCLIV, 19-21. As Defoe put it elsewhere, concerning another castaway: "I had a parcel of money.. Alas! There the nasty, useless, stuff lay. I had no manner of business for it.” Defoe, The Life and Adventures of Robinson Crusoe , (1719), Harmondsworth, Penguin (1985), 140. see also James Thompson, Models of Value: Eighteenth Century Political Economy and the Novel, Durham NC, Duke University Press (1999, ch 3.

${ }^{21}$ John and Jean Yolton (eds), John Locke: Some Thoughts Concerning Education, Oxford, OUP (1989); Lawrence Klein (ed), Third Earl of Shaftesbury: Characteristics of Men, Manners and Opinions, Cambridge CUP (1999).

${ }^{22}$ David Hume, Enquiries Concerning the Human Understanding and the Principles of Morals, Oxford, OUP (1972); Essays Moral, Political and Literary, Essay IV, Of the First Principles of Government, Indianapolis, Liberty Collection (1987).

${ }^{23}$ Jacques Lacan, My Teaching, London, Verso (2008), 37.
} 
Lacan's connection between the subject and the social being could not, of course be clearer. The subject, for Lacan, is not the interpellated dolt of Althusserian structuralism, the bearer, as lawyer, priest or teacher, of systems which only Marxian science can interpret and perhaps unravel. Nevertheless, for Lacan, s/he cannot avoid speaking the language, desiring the desire of the Big Other in order to avoid a psychotic abandonment of the social world. The nostalgic sweetness, the being-at-one with the world conjured at the breast is followed so briefly with what becomes clear to the becoming-subject as the illusion of separation, independence and wholeness. Jouissance captures the moment in two ways. The joy-pleasure-jouisance of independence is soon dissipated by the uncoordinated experience of dwelling in a body still physically dependent at a basic level.. But jouissance, enjoyment, has, of course another and identical meaning in French and common property law which is not part of infantile experience, but of an analogous adult social interdependence. How often do, for example, law students need to be reminded that that ambiguous term "ownership" is not the sweet and joyous relation between a person and a thing - as the proud owner of a new Mercedes or a large house might imagine -, but a dependence, a recognition by anOther's gaze resembling that of the mirror, or of the carer's gaze reposed upon the infant, and one indulged by political society on the claimant of wealth? ${ }^{24}$ At the intersection of psychoanalysis and semiotics, the jouissance of the property is "inaugurated" as authentic, true.

Jouissance, enjoyment, requires another for its very existence. This is, on the reading of Lacan I use here, a castration which escapes the lingering biologism of Freud. We are not at home if we are not in the Other's home, but, at the risk of offending Lacanian purists, it seems to me that the overwhelming necessity for the desire of the Other, the requirement of speaking its language in order to partake of its truth and accept the communion of others, little objects - les objets petits autres - both permit and require: academic collegiality and recognition, the decline of which into a banality Bourdieu regretted; membership of a union or a party; as we have seen, the military, the local golf club or free-masonry.

Before moving to a discussion of how early modern England comes to have meanings for its subjects, to speak its subjects, to employ a Lacanianism, it is necessary to return to Tindemans and his connection of the psyche and the polis - it would be unsurprising if the family, the community and the polis were the means by which the terrifying chaos of the subject were held in check. Arendt's observation is different, but related: that to be human is to be a biological specimen merely. Nobody denied that women, slaves and foreigners were human, but to be a subject was to be the member of political society, which, in turn, held back chaos. And membership of a political community is precisely what, Wilson tells us, English and after the Union of England and Scotland in 1707 and

\footnotetext{
${ }^{24}$ One thinks, here, of course of the work of Pierre Bourdieu, in particular, Distinction: A Social Critique of the Judgement of Taste, New York, RKP (1984), on the cultural dimension of law's political recognition of important, apparently individual accomplishments of social status by virtue of possession or cultural achievement.
} 
white free property-owners of the British Atlantic Empire, men and, increasingly, women, formally enfranchised or not, felt themselves to be, in particular ways ${ }^{25}$.

How did this feeling of membership come about? It pays to begin with where we seem to find ourselves, in the present, but what is undoubtedly not the end. We find a convergence of authorizing, meaning-giving and meaning-renewal in several sources. In innumerable colorful magazines obsolescently ranked in British supermarket queues we find references to the English thousand-year monarchy, a notion that Queen Elizabeth herself, we are told, subscribes to. She was supported a number of years ago by the then Department of the Environment, which issued a chart, The Kings and Queens of England. ${ }^{26}$ We know, of course, that there was not a British monarchy until the union of the Crowns, and even then largely in the fantasy of Elizabeth's successor, James VI of Scotland. We know, too, that until the late fifteenth century England was ruled by French speakers, for whom the land was a northern possession valuable largely for its wool exports. $^{27}$

So there is, in Nairn's term, an "enchantment" worthy of Shakespeare, who has Titania, Queen of the fairies, with a magic liquor placed by Oberon in her eyes whilst asleep, put under such a spell that

The next thing then, she waking, looks upon

Be it on lion, bear, or wolf or bull

On meddling monkey or on brute ape

She shall pursue it with the soul of love ${ }^{28}$.

A millennial monarchy, has oddly been revered and deemed to have been begun with the somewhat abrupt arrival of William Duke of Normandy, himself an ethnic Viking,at Hastings in 1066, rather than with the Saxons Aethelred, 916, Edmund or the Danish Cnut, both counted Kings of England in 1016, Cnut after Edmund's death.

The enchanted continuity survived the Tudor claim to legitimacy. In his successful claim to the throne, Henry VII, the first Tudor, argued that the Tudors were, after all, descended from the Britons, Celts, like the Bretons and the Cornish, who had unavailingly sought to defend their land from the Saxons. His eldest son, had he survived, would have been King Arthur, in honor of the founder of the Round Table in a Camelot associated in Anglophone mythology with the ancient Britons. Oddities multiply, as they do in myth, especially, perhaps, myths of nationhood, beginnings and on-going traditions. In Ivanhoe, a hugely popular novel in the early nineteenth century, Walter Scott's heroes were now no longer the Celtic peoples but the Saxons, their natural devotion to the Teutonic

\footnotetext{
${ }^{25}$ Kathleen Wilson, The Sense of the People: Politics, Culture and Imperialism in England , Cambridge, CUP (1992); A New Imperial History: Culture, Identity, History, Cambridge MA Harvard University Press (1999); Empire, Gender and Modernity in the Eighteenth Century in Philippa Levine (ed), Gender and Empire, Oxford, OUP (2004).

${ }^{26}$ London, HMSO (1967). The chart was, it proclaims, discovered in the Kaiser's Alcove at Osborne House, one of Queen Victoria's favorite retreats.

${ }^{27}$ Norman Davies, The Isles: A History, Oxford, OUP (1999).

${ }^{28}$ William Shakespeare, A Midsummer Night's Dream Act II Sc i.
} 
freedoms of Tacitus's German forests, and the conversion to those freedoms of such of the Normans who were well-disposed to them, symbolized in the marriage of Rowena to Wilfred of Ivanhoe with the blessing of Richard, Coeur de Lion, and with the unlikely assistance of the Saxon outlaw, Robin of Locksley (Robin Hood). Published in 1819, Ivanhoe occupies a place of reconciliation between the "Norman Yoke" beliefs of the $17^{\text {th }}$ century radicals who saw their opposition to Stuart Absolutism in terms of the Norman tyranny over Germanic freedoms. This pre-Victorian Germanic romanticism, fueled later, no doubt by Victoria's background and her devotion to her German consort, Prince Albert, gained semiotic and even legal-semiotic momentum during the $19^{\text {th }}$ century, with writers like Edward Freeman ${ }^{29}$ celebrating a constitutional Anglo-Saxondom of freedom that would ally England, Germany and possibly the United States, dominating and civilizing the world. We see ominous echoes of this expansive and imperialist mythology today, with "coalitions of the willing", "axes of evil" and the like. Germany naturally lost its connection with Teutonic liberties in the discourse of constitutional freedom with the naval rivalry and conflicts of the early and mid-twentieth century, to the point where the royal appendages, the Battenbergs eventually considered it prudent to Anglicize their family name to Mountbatten.

As a retrospect, Kirsty Duncanson assembles the curious story of the millennial monarchy and explains the on-going "enchantment" brilliantly in her account of the media coverage of Princess Diana's funeral. “The people’s princess”, Prime Minister Blair characterized her as: but which people? In the early $18^{\text {th }}$ century, Defoe had satirized English pretensions to racial superiority with his references to the "mongrel race”. As Duncanson observes, BBC footage at least noticed the multi-ethnic nature of those who laid the wreaths, flowers and other objects placed outside the Palace, and as the cortege plied its way to Diana's ancestral home, the present author, in Dublin at the time, read in the Irish Independent that England (not Britain - an editorial oversight?) had in this moment of grief, achieved a kind of reconciliation with Ireland. A monarchy which had oppressed the Irish, mostly Catholics, but also Protestants, until Westminster was handed the grisly task, was forgiven. Duncanson unpicks the meanings. The cortege of black cars accompanying the hearse to Diana Spencer's ancestral home, drove slowly, she says, through the downlands, the countryside which, according to her, has always been made to represent England. Britains's, that is, England's greatness, according to Slater, Ishiguro's English butler ${ }^{30}$ consists in the unassuming nature of its landscape, which makes no immodest demands in the form of mountains or chasms. The "southern rural masquerade" as Duncanson puts it, presents to the viewer "panoramic vistas of country estates, pastoral fields.. quaintly preserved villages.. hedgerows and cottage gardens". ${ }^{31}$

\footnotetext{
${ }^{29}$ Edward Freeman, The Growth of the English Constitution from Earliest Times, London, Macmillan (1876).

${ }^{30}$ Kazuro Ishiguro, Remains of the Day, London, Faber and Faber (1989).

${ }^{31}$ Kirsty Duncanson, Embodiments of the Constitution in the Romanticised Narratives of the Funeral of Diana, Princess of Wales and Four Weddings and a Funeral (2008) 28 Australian Feminist Law Journal 121-150; Imagining Constitutions: Film, Event, Text, unpublished PhD thesis, University of Melbourne (2008), 96, 92.
} 
What is being represented theatrically for the present is the eternal, "authentic" England which stands for Great Britain, the "Home" Counties", a phrase that summarizes much. Diana's was a progress so beloved and used with such effectiveness in the construction of “Good Queen Bess” for fifteenth century Londoners. ${ }^{32}$ The script to which Duncanson refers not only, in a paradoxical, but also symmetrical way, to Rupert Brooke's unheimlich being at home not-here; but it also comes straight from Stanley Baldwin, an industrialist's son whose interwar political career was significantly based on evocations, an invincible romance of an ancient land that never was, broadcast, ironically over the radio, then a new medium. To a largely urban population, he spoke of the "real" England, a Saxonism which artfully avoided the Germanism of the Victorian legal scholars, mesmerizing Tyneside shipbuilders, Sheffield steelworkers and Liverpool dockworkers, as well, of course, the middle class, with their country estate suburban gardens, with visions of the haywain at dusk ${ }^{33}$, the thwack of the squire's willow cricket bat against the tenant's leather ball on the village green.

The sounds of England, the tinkle of the hammer on the anvil in the country smithy, the corncrake on a dewy morning, the sound of a whetstone and the sight of a plow team coming across the brow of a hill.. for centuries, the one eternal sight of England. ${ }^{34}$

The mysterious corncrake, the haywain, summoned to the present in its very absence, and the country smithy, no doubt long replaced by the Baldwin family industries, together form the mise-en-scene, an enchantment from which Princess Diana will not awaken, as in The Sleeping Beauty, but in which, in precise symmetry, I have suggested, to Brooke's converting into England "some corner of a foreign field", she will return to her own field, under an "English heaven", of course, re-awakening, not herself, but that powerful myth of authority, continuity. Sovereignty is theater, of course; it is a site where certain collective identities can be and indeed must be represented. But theater is where, not only certainty, but where innovation and the anxieties associated with this are generated. The enchantment to which Baldwin and Duncanson refer, in very different registers, are responses to modern crises about what the British monarchy means in constitutional and political terms. As a politician, Baldwin worked in a climate in which the triumph of Bolshevism in Russia, significant labor unrest domestically, economic depression, later Fascism elsewhere, and eventually the Abdication crisis of 1937 rendered the comfortable-seeming, but actually precarious constitutional monarchy in a state of disrepair. Duncanson writes of a period in which a manifestly dysfunctional Royal family and a constitutionally devolved state, Scotland, Wales, Ireland and England, the latter in particular uncertain of its position in the European Union again question the comforting enchantment of constitutional monarchy. The return of Diana to her ancestral corner of

\footnotetext{
${ }^{32}$ Leanda de Lisle, After Elizabeth: The Rise of James of Scotland and the Struggle for the Throne of England, New York, Ballantine Books (2005) argues that the failure of Elizabeth's successor to use theater "as a symbol of national aspirations" contributed much to the alienation and disintegration that was to characterize seventeenth century England. "..the nation that shaped and worshipped Gloriana never forgave him for it" (289).

33 "wain" was a term much favored by Morris, Rossetti and others, whose preferred nomenclature for the ubiquitous urban tram or omnibus, was "folk wain".

${ }^{34}$ http://news.bbc.co.uk/1/hi/special_report/1997
} 
her native land was a powerful if transient re-enactment of the legal and constitutional unity which the "Home Counties" conceptually underlies, but a new meaning, a new semiotics of legality will be required. My task here is, however, to investigate the old meaning, since, I believe it does help provide a vocabulary for the future.

\section{3) The Play in the English State}

Major politico-religious struggles troubled Christian Europe in the $17^{\text {th }}$ century. The devastation would be difficult to overstate, especially in the German territories torn apart by Protestantism and Catholicism. But in 1648 at the Treaties of Westphalia a serious attempt was made to reach accommodation over religious differences by containing them within dynastic-territorial boundaries, within each of which the sovereign would for the most part determine the form of religious worship required of its subjects without legitimate interference from other sovereigns. The problems faced in the British Isles were not resolvable by this more or less tidy construction, aligning religion with dynasty. There was no sovereign law, since Scots law maintained (and still maintains) its distinction from the English dualism of common law and equity. The two established churches of the Stuart and subsequent monarchies, the Calvinist Kirk in Scotland, the English High Church, bordering, according to its critics, on Papism, and the Church of England latitudinarianisms, not to mention Irish Catholicism, were only the beginning. Protestant dissenters of several varieties, often at odds with each other, also came to be commercially powerful men - largely, though not exclusively men - vital to commerce and early industry, with intellectually formidable grammar schools and higher education academies whose graduates frequently spent time at Scottish Universities when they became world leaders of institutionalized intellectual endeavor. If the ideological kaleidoscope, later symbolized in the multination Union flag, were to be translated, how were the colors to be resolved into a visual pictograph as representative of capitalist agrarian England as those somber paintings representing the Netherland merchants of a slightly earlier era? The jolly stout squire-magistrate and the orderly fields of a deceptively bucolic estate, with productive enclosures took the place of the somber solemnity of the Dutch masters' productions. Gainsborough and Constable are later, but reflect a particular tradition: Britain is its English landscape, its Royalty return to it, and its dead occupy an eternal England. ${ }^{35}$

These, then, were the materials available. What the landlords who provided the basis of England's eventual global supremacy required was stability and freedom in order, not merely to effect agricultural improvement, but also exploit the coal and other wealth on their estates, freedom of property for themselves, which they equated with, as Thompson has assured us, as freedom for all. ${ }^{36}$ What they emphatically did not need was the stability of Hobbes' "mortall god", the sovereign arch-enemy of the common law and the code of property. I have used Shakespeare as an example of alternative, theatrically available resources of Englishness as it could in some circles become, a land in which (at least English) fairness rather than unjustified coercion prevailed. The slow-witted John

\footnotetext{
${ }^{35}$ Katherine Tidrick, Empire and the English Character: The Illusion of Authority, London, IB Tauris (2009).

${ }^{36}$ EP Thompson, Whigs and Hunters, London, Allen Lane (1974), Conclusion.
} 
Bull underlying the constitutional basis of the early industrial revolution, often puzzled, but always apparently fair and with the nous and muscle to impose his view of fairness on the world emerges from an amalgam of Shakespeare's Sir John Falstaff and the nimbleminded Henry of Henry IV Part I . Shakespeare was not a prescient or even historically accurate writer, or even a writer whose dramatic locations were generally, overtly, if English, England. He was an entertainer, not a didact like, perhaps, Brecht, in the twentieth century. His radicalism lay, like that of his contemporaries, in dramatic, not political innovation; his importance for political consciousness lies in his providing a vocabulary and in which the issues that arose later could be expressed.

He was an East Midlander who spoke to audiences whose accent became standard English and who was probably accessible only to the common folk who lived in London and the midland counties and to the aristocrats who had begun to assemble in the capital for a few months each year, eventually to accomplish the downfall of the Stuarts and the end of sovereignty by stubbornly assembling in a regular Parliament made national with the aid of a Shakespearean consciousness. Boxed in by a Tudor monarchy suspicious of criticism and by the need to please a moderately literate audience with a power of concentration at the Globe and other theaters, his dramas created the possibility of an England. A contemporary of Sir Edward Coke, he created, with Coke, an England of law. No semiotics of law could ignore this.

At a time when, like most Europeans, most English people were conscious of little beyond their locality - the Cornish spoke Cornish, the Welsh, Welsh, the Irish Gaelic and most of the Scots Gallic - a sliver of England running, maybe from Nottingham, through Stratford, to London, who spoke some version of Shakespeare's English and discovered through theater, an England and thus an English subjectivity underlying a fantasy of constitutionalism and common law. The theatrical myth of Henry's oration in Henry $V$ at the siege of Harflour may have meant little in Yorkshire, Northumberland or Penzance with its invocation of "Harry, England and St George.. Once more into the breach, dear friends, once more/Or close up the wall with our English dead" 37 - were it not for the memory of the Marian persecutions, the attempt by Elizabeth's predecessor to reverse the Reformation, persecuting Protestants in the process. The enormously successful response to this experience after Mary's death, Foxe's Book of Martyrs, (physically enormous, too: its second edition was 2,300 pages long, lavished with gruesome woodcuts depicting the fate of Mary's victims). Henry V was first performed in 1599, eleven years after the defeat by England of Spain's attempt to invade and impose the Inquisition on England. Mary's reign and the threat of a very powerful Catholic enemy formed a joint trauma that cemented England to its growing number of Protestantisms.

I want to turn to Shakespeare's problematization of the subject shortly, since plainly, in order for there to be an imagining national subject, in Anderson's terms, or, in Lacan's terms, a subject which yearns for the desire of the Big Other and we have to have some idea of what that subject is, how it comes to be. But meanwhile I want to notice the Spanish threat as it appears in another, perhaps less obvious context, and slightly differently, the "comedy" play, The Merchant of Venice, performed slightly earlier than

${ }^{373737}$ William Shakespeare, Henry V, Act III Sc ii., 
Henry V, in 1596/7 . It portrays a very English Venice, full of very English Venetians, with, as many educated and perhaps less well-educated Englishmen and women would have appreciated, certain problems to do with commerce. In 1582, 1589 and then in 1598, the Hakluyt brothers published several texts rehearsing no doubt familiar aspirations and inadvertently evoking familiar fears about the meaning of the new world of commerce. ${ }^{38}$ The English, the Hakluyts felt, were gradually catching up with rivals such as the Portuguese, the French and the Spanish in terms of "discoveries" and what these discoveries seemed to contemporaries to promise: trade and wealth. The merchant adventurers, the Muscovy Company, had already been formed in 1555 with these aims in mind.

But traders needed to pool resources and raise loans to buy cargoes and fit out ships to send on dangerous voyages to often little-known lands. Once sail was set, all that underwrote the cargoes now afloat, was the paper held by the merchants and their financiers indicating their shares of the risk they had each undertaken and of the apprehended returns to which they were therefore entitled, written promises, not specie or real property. This was, as Defoe was to put it, "secret money", the equivalent of the Bank of England's "Promise to pay the Bearer on demand" the sum of one pound which, in times of crisis when most assurance is needed, and since 1926, promised simply another note with the same promise, Lacan's endless play of the signifier. Defoe was, naturally, alive to the fact that specie and land were also "real wealth" only within certain political and legal realities, semiotic legalities by no means universal; but to many early moderns, this was not so clear, unless they were themselves merchants, who dealt all the time with the paper promises, but with the publicity given to voyages and discoveries it was becoming so.

The Merchant does many things, one of which is skillfully to merge romance, commerce and reassurance, staged in response to anxiety. The play opens with Antonio, the personification of the psychoanalytic uncanny. He is, he says, "so sad", wearying himself and, he appreciates, his (male) friends with his malady:

But how I caught it, found it or came by it, What stuff 'tis made of, whereof it is born I am to learn; And such a want-wit sadness makes of me That I have much ado to know myself. ${ }^{39}$

His un-homedness, his not knowing himself, parallels his wealth, which, dispatched overseas is, as the saying goes, all at sea. Where it is, save as represented on paper, is uncertain. The conversation immediately following in Act I, among his friends, in Sc i, confirms the anxiety provoked by the thought of precarious wealth, now so obviously dependent (like the subject) on promises and the vagaries of nature. Meanwhile, his

${ }^{38}$ See Kenneth Andrews, Trade, Plunder and Settlement: Maritime Enterprise and the Genesis of the British Empire 1480-1630, Cambridge, CUP (1986) for the importance of the Hakluyts in the areas of discussion on the issues .

${ }^{39}$ William Shakespeare, The Merchant of Venice, Act I Sc i. 
friend Bassanio, impecunious, seeks the hand of Portia, a wealthy heiress between whom there has developed a mutual love. Bassanio seeks a loan from Antonio to pursue his suit, and Antonio has no immediate option than to borrow from Shylock, a Jewish moneylender. The condition of the loan contained in a bond guaranteed by Antonio is, as every reader will know, that if the loan, when due, is not paid promptly and in full, Shylock will be entitled to a pound of the merchant's flesh.

The significance of Shylock's Jewishness is not, I think, primarily anti-semitic. Like Catholics, Jews were permitted in Elizabethan England to observe their religious rites in private, unless their intentions were treasonous to the state - which was more likely among some Catholics than among Jews, although Shylock's intentions did, in fact, turn out to involve treachery to Venice. Spanish absolutism represented alien-ness a continuing threat to England until the early decades of the sixteenth century - and were much more anti-semitic and anti-Moorish as well as more anti-Protestant than the small community of Jews, largely in London. Shylock is, rather than principally Jewish, the symbolic alien, impervious to English/Venetian mores in ways attributed by the English, to Spain, not surprisingly, perhaps, given the Inquisition and the attempt by Spain to impose it on England only eight years before the performance of the play..

Bassanio and Portia marry, as do Portia’s maid, Nerissa and Bassanio’s friend, Gratiano. In the final act, Act $\mathrm{V}$, the two bewildered men are the butt of the women's humor and whilst there is an amicable resolution and while it is clear that their loves involve an emotional equality, it is equally clear that Portia is the superior in intellect and strategic intelligence, not merely wealth. The invasion fleet had earlier drawn close, though. Antonio's wealth has been rumored to have foundered off the English Goodwin Sands and the bond falls due. Shylock, "a stony adversary, an inhuman wretch/Uncapable of pity and empty/From any dram of mercy" threatens death because the severing of a pound of flesh would end Antonio's life. He rejects Bassanio's offer of money from his wife's fortune, for the due date has passed. He must have his due. Credit, Shylock's bond, of course, capable, it seems of any perversion, but nevertheless an instrument more familiar than the paper, promissory notes with which a wider public were becoming familiar from the Lombards, Hanse merchants and others, seemed confirmed as unreliable and threatening in a changing world. The flinty remorselessness of the alien, Jewish, Shylock bearing down on Antonio, apparently backed by Venetian law, surely reflected the awesome fleet commanded by the alien Catholic, Medina Sidonia, with its 17000 soldiers and 7000 sailors bearing down on England and the Virgin Queen, whose remarkable intellect, choice of advisors and strategic ability to be Good Queen Bess to the necessary parts of England, politically and geographically, could only have been Portia.

In the drama, the laws of Venice/England are at stake. If the Duke's court denies Shylock his promissory rights, what is to become of its commerce, based on promises enforced by its courts? If it enforces Shylock's apparently strict rights, what, on the other hand, does it become but an agent of cruelty comparable to the Inquisition? However, we are in the era of the legal magician, Sir Edward Coke, barrister since 1578 and Solicitor-General when The Merchant was first performed, later a judge and Parliamentarian. The reassurances 
contained in the drama concerning the emerging symptoms of modernity begin to come into view. Coke's own historical significance is now seen to lie in his celebrated opposition to the absolutist pretensions of James VI/I (Elizabeth's successor) to occupy a position outside the law. Coke's response was to quote Bracton (1210-68): quod Rex non debet esse homine, sed deo et lege - the King is subject to none but God and the law. In other words, Coke is championing government as a public rather than a private space. But within the public space of the law, the possibility of creativity was considerable and Coke's economic thinking favored credit and competition and opposed monopolies. He was a modern.

On stage, a "learned doctor", bearing letters of recommendation from a well-known lawyer, appears in Venice to act as judge examining in the case of Shylock's bond. It is, of course Portia in disguise, accompanied by her “male” clerk, Nerisssa. Just as Drake's ships lure the Spanish invasion fleet into winds more favorable to the nimbler and betterarmed, but fewer English vessels, so Portia lures Shylock, appealing at first to his mercy, knowing that he has none, allowing him to demand the exact rights which the bond awards him and then telling him that he is entitled to them: "A pound of that same merchant's flesh is thine/ The court awards it and the law doth give it". But, "tarry a little; there is something else./The bond doth give thee here no jot of blood". " 40 The alien is defeated, and in defeat loses his assets, but also, in being compelled to become a Christian, his strangeness is rendered dramatically safe. Finally, news arrives in Act V that Antonio's vessels containing his wealth in their cargoes, are safe. Thanks to the subtlety of Portia, law has produced justice without subverting itself, an alien threat has bee averted and the new (to the English) forms of commerce, using new legal instruments, have proved themselves reliable. All the play's lovers may safely go to bed.

In the Lacanian terms explained in seminars XII and XIII, one could say that Shakespeare's comedies represent a symptom, more accurately a sinthome, which J-A Miller relates to the question, “Am I (i.e. as a subject) constructing my fundamental fantasy correctly?" ${ }^{41}$; and Evans, like Lacan, refers to the sinthome as a knot, or a stitching point, preventing different dimensions or surfaces of, say, a quilt, from sliding uncontrollably from one another. ${ }^{42}$ If there is, as Zizek suggests, to put things another way, no meta-language available for the subject to define itself, then the knot represents "all you had to forget so that you can swim in your everyday, certainty, it enframes the very frame which confers meaning on your life, it structures the horizon within which things make sense to you; if we unknot it, you will lose the ground from under your feet”. ${ }^{43}$ Shakespeare's grounds are order and, if one thinks of The Merchant, the capacity of order to accommodate change. New and potentially upsetting signifiers of commercial practices, the laws of credit, can be made fair and reasonable; the outrageous threats to legitimate order embodied in Macbeth, his unnatural wife and the witches are finally, if

\footnotetext{
40 The Merchant, Act IV Sc i.

${ }^{41}$ Jacques-Alain Miller, The Sinthome, a Mixture of Symptom and Fantasy, Iin Veronique Voruz and Bogdan Wolf (eds), The Later Lacan, Albany, State University of New York Press (2007), 69.

42 Dylan Evans, An Introductory Dictionary of Lacanian Psycho-analysis, London, Routledge (1996), 1889.

43 Slavoz Zizek, Enjoy Your Symptom! New York, Routledge (1992), 14,15.
} 
bloodily resolved. Only in Hamlet and Lear, arguably, does disorder threaten "the ground under your feet" as the voyagers on their perhaps uncanny journeys to the limits of the commonsensical flat earth were threatened by tipping over the limit of the known into the unknowable abyss.

The subject which performs in Shakespeare's texts - and I have suggested that s/he is the reflection or articulation of an English subject of the early modern period - is a form of sinthome, anchoring the person in an intelligible but not a logically necessary place. In As You Like It, the wise fool, Jaques observes that

All the world's a stage

And all the men and women merely players:

They have their exits and their entrances;

And one man in his time plays many parts. ${ }^{44}$

Acting was not for Shakespeare or his audiences what twentieth century sociology would see as playing a role, that is, being an essential person prior to the persona exhibited on the stage. To make a trivial point, since women did not generally perform on the sixteenth century stage, audiences followed the logic of women who were actually boys disguised as women further disguising themselves as men, as Portia, Nerissa and many other dramatic actors did. Less trivially, serious actors in modern times speak of themselves as becoming the character whom they represent. Hamlet reflects, having witnessed a brief performance of the "players” visiting Elsinore:

Is it not monstrous that this player here

But in a fiction, in a dream of passion

Could force his soul so to his own conceit

That from her working all his visage wann'd;

Tears in his eyes, distraction in's aspect

A broken voice, and his whole function suiting

With forms to his conceit? And all for nothing!

For Hecuba!

What's Hecuba to him or he to Hecuba

That he should weep for her? ${ }^{45}$

Of course it is not monstrous; Hamlet is contrasting the player's knowing how to be a subject in a particular context with his own failure to be such in relation to his father's murder. Grimmer still is Macbeth's reaction to his own destruction of the context in which he can be a proper subject by killing the legitimate king, usurping his throne and murdering his own associate, Banquo.

Tomorrow and tomorrow and tomorrow

Creeps in this petty pace from day to day

To the last syllable of recorded time;

\footnotetext{
${ }^{44}$ As You Like It Act II sc vii

${ }^{45}$ Hamlet, Prince of Denmark, Act II Sc ii.
} 
And all our yesterdays have lighted fools

The way to dusty death. Out, out, brief candle!

Life's just a walking shadow, a poor player

That struts and frets his hour upon the stage

And then is heard no more; it is a tale

Told by an idiot, full of sound and fury

Signifying nothing. ${ }^{46}$

- save the signifier of falsity. It is this always-disturbing absence of a signified that Tom Stoppard's Rosencranz and Guidenstern Are Dead exploits brilliantly. The eponymous pair is given, as it were, lives of their own, by Stoppard's text in which they obey two laws, the Law of the Father, that is, the text of the play which speaks them, and the secular law of Claudius, whom they understand to be the proper king. They recite the lines they have been given by Shakespeare, but when the stage is empty of all but themselves, Stoppard has them come to realize that little of either law makes sense to them; and then, in a trick revealed to the audience but not to them, they are killed.

Hamlet was performed in the last years of Elizabeth, who died in 1603, Macbeth in the early years of her successor, James, a man whose contempt for his people was soon equaled by their dislike of him. In understanding English seventeenth century politics, for which James set the tone, it is useful to notice Jeanne Schroeder's distinction between what she sees as a male-gendered and a female-gendered approach to castration in psycho-analysis, and we do not have to interpret this distinction in the biological sense. The response she characterizes as male is one of denial that there could be no signified. 'He' "constantly tries to cover over the holes in the symbolic order and to reconcile what cannot be reconciled, which perfectly characterized the behavior of James VI/I. Neither England nor Scotland, very manifestly, would countenance an absolute momarch, with pretensions above Parliament or the common law, in which there was always a gap, room for debate. The task for what has been described to me as the "alpha male" - not a biological entity - is to ensure that there are no gaps in the law. The 'feminine' subject "in contrast, accepts not only the fact of her own castration, but its consequences.." S/he must speak the language of the other and "this acceptance can result in the creative freedom that permits true criticism and the possibility of a new symbolic order". ${ }^{47}$

\section{4) The Play of the English State.}

As monarchs with absolutist pretensions, the Stuarts, from James VI/I in 1603 to James VII/II, who was exiled to St Germains in 1688, they clearly fall into Schroeder's first category. James I's political writings make it clear that he regarded himself as occupying what Agamben would describe as a "state of exception". ${ }^{48}$ Judges, he felt, were mere delegates of the crown, whose decisions could properly be set aside by the king.

\footnotetext{
${ }^{46}$ Macbeth Act V Sc vii.

${ }^{47}$ Jeanne Schroeder, The Hysterical Attorney: The Legal Advocate within Lacanian Discourse Theory (2000) International Journal for the Semiotics of Law 181-213, 201-2.

${ }^{48}$ Giorgio Agamben, Homo Sacer: Sovereign Power and Bare Life, Stanford, Stanford University Press (1998).
} 
Parliament should not meddle in high matters of state or offer advice to the crown about how its affairs should be conducted. The monarchy would comply with the law to the extent it regarded it as acceptable. ${ }^{49}$ There could be no gaps in the law because the edicts of the crown would always fill them, no uncertainty allowing creative change except as monarchically approved. Nothing indicates that his Stuart successors felt differently.

The 1629 Petition of Right “humbly” addressed to the king, by now Charles I, insisting that the taxing power on which Royal expenditure depended, was Parliament's alone, and that free men were entitled to "due process of law where their persons or property were at stake" - this was a theatrical dress rehearsal for what was to come, something quite different, both from the traditional expression of humility in the Petition and from the political-ideological nature of the struggle and concerned with the basis of law and the nature of the subject: the critical battles of Marston Moor and Naseby. Of the Royal army, perhaps only its leaders fully understood the radical nature of their opponents' positions. The remainder, professionally competent were perhaps unreflectingly loyal to the their social superiors and the status quo, represented above all in the God's representative on earth, the king. On the parliamentarian side, a new political and entirely new consciousness of political equality is evidenced in suspicions among the rank and file, especially of the Eastern Association soldiers, committed to the new consciousness that Marston Moor could have been a more decisive victory, and that part anyway of the leadership harbored hopes of reconciliation with the king. In one way it was decisive theater, the discipline and commitment of the Eastern Association troops, added to their new political awareness creating a new subject. ${ }^{50}$

In another way, Marston Moor was theatrically incomplete, as Naseby, the crucial site of the defeat of Royal forces was not. Captured Royal documents indicating Charles' willingness to involve European absolutist powers on his side completely ended any hopes by the non-radical parliamentary leadership that some reconciliation involving minor constitutional adjustments might be possible. But Naseby made finally possible, not a consensus, certainly, but a new subject of legality, a new terrain of struggle in which, as Purkiss suggests in the quotation at the heading of the article, the rights of man (and subsequently persons) comes into existence as the meaning, or justification of law. Subsequent to Naseby, as a prelude to my final piece of theater, the army produced

An Agreement of the People for a firm and present peace, Upon grounds of common right and freedom; As it was proposed by the Agents the five regiments of horse and since by the general approbation of the Army, offered to the joint concurrence of all the free COMMONS OF ENGLAND ${ }^{51}$.

\footnotetext{
${ }^{49}$ Charles McIlwain (ed), The Political Writings of James I, Cambridge MA Harvard University Press (1918).

${ }^{50}$ GE Aylmer, Rebellion or Revolution? England From Civil War to Restoration, Oxford, OUP (1987), ch 3; Brian Manning, The English People and the English Revolution, London, Penguin (1976), ch 9.

${ }^{51}$ It is worth noting that the House of that name was understood to represent, or stand for a greater commons, that of the free Englishman. For many historians, the army was far more representative of this subject, more literate and politically engaged in the seventeenth century until the mid-nineteenth.
} 
Nine regiments of horse and seven of foot are eventually mentioned specifically, the Army generally and the Commons (i.e.) the common people are invoked. ${ }^{52}$

Subsequent debates among delegates (“agitators”) at Putney Church in 1647-9 demonstrate that many at least of the Parliamentary soldiers knew what they were fighting for, and it was for a fundamental change to the constitution. Presbyterian Calvinism was socially egalitarian, but Roots writes that "for many, the belief of the sovereignty of the people no longer required such dubious underpinnings as Calvinistic theology could be made to yield. It appeared self-evident". ${ }^{33}$ Among the most articulate of the Agitators sent by regiments in the Parliamentary army to speak for them about the amendments necessary to secure English freedoms at Putney, was Colonel Rainsborough. He asks what the army has fought for if the constitution is to remain the same as before. He rejects the conservatives' assertion that only those with a substantial proprietal stake in the country should have the vote, for two reasons. First, he argues that "if it be a property (that the wealthy possess) "it is a property by a law". In that case it is preceded by a more fundamental property "- property in the franchise mandating the law of property in land. "I would fain know how that (i.e. the franchise) comes to be the property of some men and not of others”. Secondly and more broadly, he argues, and I quote him at length

For really I think that the poorest he that is in England hath a life to live as the greatest he; and therefore, truly sir, I think that every man that is to live under a government ought first by his own consent to put himself under that government; and I do think that the poorest man in England is not at all bound in a strict sense to that government that he hath not had a voice to put himself under; and I am confident that when I have heard the reasons against it something will be said to answer those reasons, insomuch that I should doubt whether he was an Englishman or no that should doubt of these things.

William Petty's contribution affirmed that "we judge that all inhabitants that have not lost their birthright should have an equal voice in elections". ${ }^{54}$

\section{Conclusion}

I have followed a number of other writers in noticing the closeness and complementariness of psychoanalytic theory and semiotics in charting the phases of subject-formation. The analysand on Freud's famous couch, with whom we began, appears a singularity, an individual, but the only meaning s/he can give to the self comes from the perceptions of the social world, however negotiated s/he tries to make this process. What much of the foregoing tells us, and what we knew already, from Lacan and Foucault, is that the inanimate means, not in some mad new age or anthropomorphic way,

\footnotetext{
52 The (First) Agreement of the People, in GE Aylmer (ed), The Levellers in the English Revolution, London, Thames and Hudson (1975), 89.

53 ASP Woodhouse (ed), Puritanism and Liberty: Being the Army Debates 1647-49 from the Clarke Manuscripts, London, Dent(1986), Introduction, 62.

${ }^{54}$ Woodhouse, op cit, 53
} 
where mountains speak and rivers and bears talk, but, as maple leaves, crucifixes and innumerable other signifiers suggest, they, as much as "law", organize subjectivity and its place in the state and its constitution. In the period with which I have been concerned, Shakespeare has created an England in which subjects created a new meaning of themselves as subjects of law - which he, no doubt could not have predicted, but he provided a language in which they could do so. Smashing graven images in places of worship, which is what Eastern Association soldiers - dubbed Ironsides by their enemies - did, is not historically unique, but to do so in the name of human equality, equality before law as well as before the law of God,as they conceived it, probably is. 